\title{
PLANTAGO MULTISCAPA, A NEWS PECIES FROM EREMAEAN AUSTRALIA, AND NOTES ON PLANTAGO IN WESTERN AUSTRALIA
}

\author{
Barbara G. Briggs \\ (Accepted for publication 14.3.1980)
}

\begin{abstract}
Briggs, Barbara G. (National Herbarium of New South Wales, Royal Botanic Gardens, Sydney, Australia 2000) 1980. Plantago multiscapa, a new species from eremaean Australia, and notes on Plantago in Western Australia. Telopea 2 (I): 77-81.-P. multiscapa (sect. Mesembrynia) is allied to $P$. drummondii Decaisne and known from the south of the Northern Territory, adjoining parts of South Australia and the far north-west of New South Wales. A lectotype is selected for the Western Australian P. exilis Decaisne and the features distinguishing it from allied species are outlined, $P$. varia $\mathrm{R}$. Br. var. exigua Pilger is referred to the synonymy of $P$. debilis $\mathrm{R}$. $\mathrm{Br}$.
\end{abstract}

A treatment of Plantaginaceae in New South Wales (Briggs, Carolin \& Pulley, 1977 ) provides some information on the majority of Plantago species of the Australian mainland. The present paper deals largely with matters arising from that study but which could not be included in a State-limited treatment. Problems requiring more field study and collecting still remain, especially in the south of Western Australia and in South Australia.

In eastern Australia the distinctions between Plantago species, although generally reliable, often depend upon a number of very inconspicuous features. The same pattern appears to apply in Western Australia (see below, P. exilis). The highly distinctive $P$. multiscapa was omitted from the earlier treatment as it had not been recorded at that time from New South Wales.

\section{(1) A new eremaean species}

\section{Plantago multiscapa B. Briggs, sp. nov.}

Herba annua deserticola sectionis Mesembryniae. Scapi multi, (3-) 15-100 numerantes. Folia linearia (1-) 3-6.5 (-12) cm longa, 0.7-2 mm lata. Bracteae deltoideae non carinatae, virides vel aliquando fusco-brunneae purpureaeve, marginibus membraneis, glabrae vel inconspicue pilosae. Capsula ellipsoidea, $3-3.6 \mathrm{~mm}$ longa, $1.8-2.4 \mathrm{~mm}$ lata, nitens, fusco-brunnea, apice rotundata. Semina 4.

Annual herb with a long, usually straight taproot. Leaves numerous, all basal, erect or spreading, narrow-linear, (1-) 3-6.5 (-12) cm long, 0.7-2 mm wide, entire or occasionally with $1-2$ inconspicuous teeth, thick and presumably fleshy when fresh, wrinkled and with an adaxial furrow when dry, coarsely (but often sparsely) pilose with short stout hairs, tapering very gradually to a slender base, the axil villous with white hairs 6-8 $\mathrm{mm}$ long, the apex blunt. Scapes numerous, (3-) 15-100 in number, $(1-)$ 5-8 $\mathrm{cm}$ long, $0.5-1 \mathrm{~mm}$ diam., densely pilose with spreading or subappressed coarse hairs. Spikes very short or up to $4 \mathrm{~cm}$ long in fruit, with 2-26 flowers, compact in flowering stage but the lower flowers widely-spaced at fruiting stage. Bracts deltoid, 1.5-3 $\mathrm{mm}$ long, 1.2-1.8 $\mathrm{mm}$ wide, not keeled but with a broad thickened central zone $\frac{1}{2}-\frac{2}{3}$ of total width and membranous margins, green or rarely dark brown or purplish, glabrous or inconspicuously pilose with short hairs, the apex sometimes minutely ciliate. Sepals elliptic, $2.5-3 \mathrm{~mm}$ long, $1.8-2.5 \mathrm{~mm}$ wide, similar to bracts in texture, colour and indumentum. Corolla: tube $2-2.5 \mathrm{~mm}$ long; lobes deltoid, $0.8-1 \mathrm{~mm}$ long, $0.5-0.6 \mathrm{~mm}$ wide, with a median brownish stripe near base. Stamens with filaments scarcely exceeding the corolla tube; anthers $0.8 \mathrm{~mm}$ long. Ovules 4 or ?5, the apical ovule not apparent or very small and 
aborted in fruiting stage. Capsule ellipsoidal, 3.0-3.6 mm long, 1.8-2.4 $\mathrm{mm}$ diam.; the lower persistent section not membranous and slightly exceeding the glossy, dark brown, upper section; the apex rounded, with a very small mucro (persistent style base). Seeds 4, yellow-brown, ellipsoidal, c. 2.3-2.8 $\mathrm{mm}$ long and $1.2 \mathrm{~mm}$ broad, flattened but slightly convex adaxially, with a thick mucilaginous layer.

Holotype: Sth Aust. Far North, Airstrip at Mokari Bore in Simpson Desert. Grid 448731, [26 $\left.16^{\circ} \mathrm{S}, 136^{\circ} 25^{\prime} \mathrm{E}\right], D$. E. Symon 9455, 28-IX-1974 (AD). IsotyPES: ADW, NSW, K.

Distribution: Towards the south of the Northern Territory, the far north of South Australia and the extreme northwest of New South Wales (Fig. 1); on swales or claypans in sand-dune country, sometimes near watercourses. Most known occurrences are around the margins of the Simpson Desert. The single record from New South Wales was collected after several years of above-average rainfall but is in an area linked to the Simpson Desert by \pm continuous sand-dune country.

Specimens Examined: Northern Territory: Central Australian South: 5 miles [8 km] SSW. of Mud Tank, $23^{\circ} 01^{\prime} \mathrm{S}, 134^{\circ} 16^{\prime} \mathrm{E}$, Latz 4332, 14.9.1973 (NT); watercourse near Andado, Crocker [7.] 1939 (AD, the specimen is also labelled 'and sandhill along Eleanor, Camp 28', but this location apparently refers to a specimen of $P$. drummondii-there is an unambiguously labelled specimen of the latter from this locality in the Tate collection in AD).

South Australia: Lake Eyre Basin: flat area between dunes 3 and 4, c. 38 miles [c. $61 \mathrm{~km}$ ] E. of Dalhousie Springs, Lothian 1544, 1572, 9.8 .1963 (AD); 30 miles [c. $48 \mathrm{~km}]$ E. from base camp [base camp $=$ c. 38 miles [c. $61 \mathrm{~km}$ ] E. of Dalhousie Springs], Lothian 1629, 10.8.1963 (AD); 2 miles [c. $3 \mathrm{~km}$ ] E. of base camp [E. of Dalhousie Springs], Lothian 1847, 12.8.1963 (AD).

New South Wales: North Far Western Plains: c. $1 \mathrm{~km}$ SE. of Middle Bore, Sturt National Park (formerly "Binerah Downs" station), Mulham 1329, 10.9.1978 (NSW).

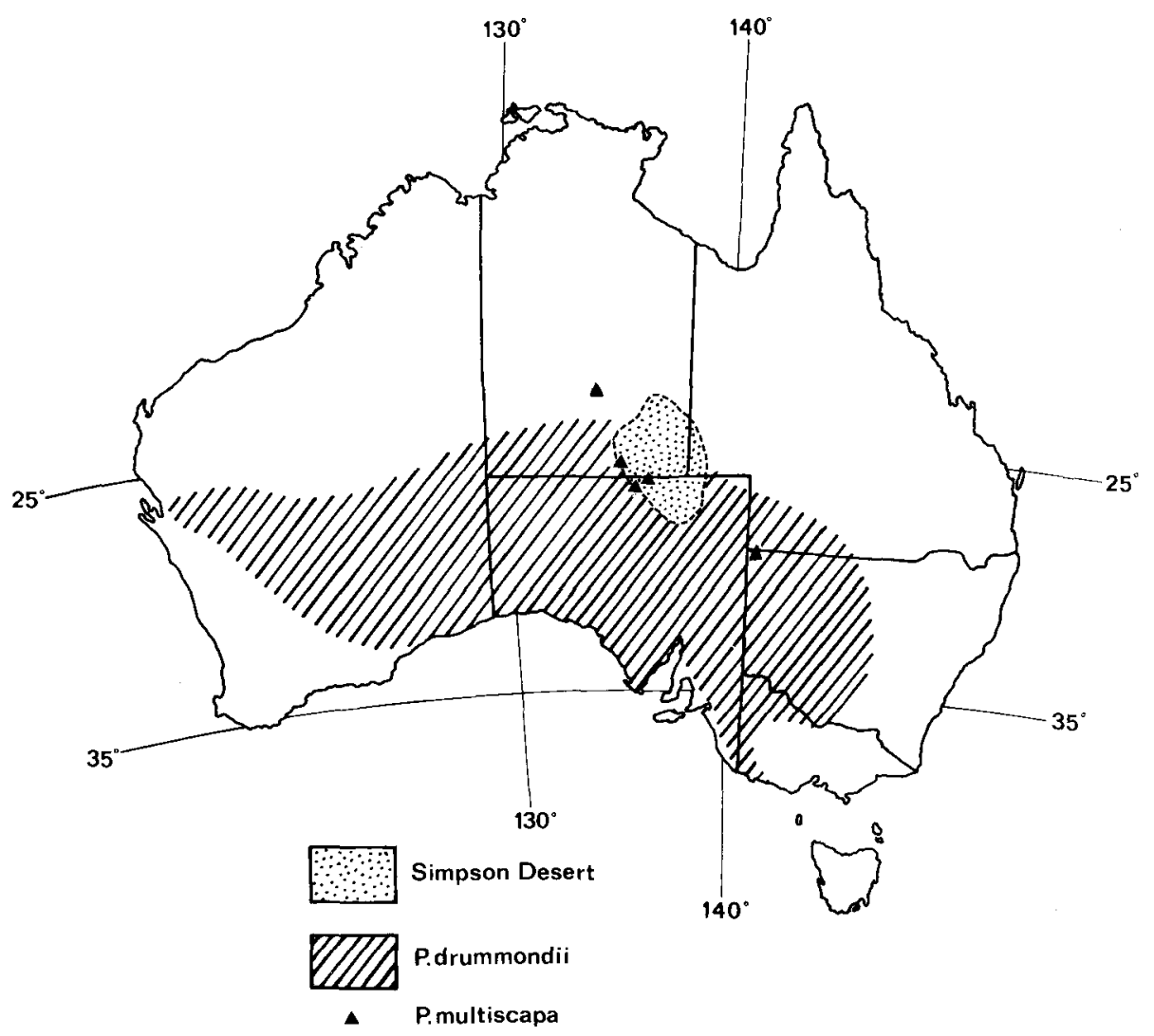

Fig. 1. Distribution of Plantago multiscapa and P. drummondii. 
Eardley (1946) and Symon (1969) referred to material of $P$. multiscapa from the margins of the Simspon Desert under the name $P$, varia $\mathrm{R}$. Br.

The annual species of arid and semi-arid Australia form a well-defined group consisting of $P$. multiscapa, $P$. drummondii Decaisne, $P$. cunninghamii Decaisne and $P$. turrifera Briggs, Carolin \& Pulley. $P$. multiscapa is most similar to $P$. drummondii but differs in the rounded capsule apex, narrow leaves and usually very numerous scapes. The other species are treated by Briggs et al. (1977). These authors note that $P$. cunninghamii is intermediate in most features between $P$. drummondii and $P$. turrifera and suggest that $P$. cunninghamii may have originated by hybridization between those two species or, alternatively, that it may be ancestral to them. The features of $P$. multiscapa are not similarly derivable from any combination of those found in allied species. At one location $(61 \mathrm{~km} \mathrm{E}$. of Dalhousie Springs) both $P$. multiscapa and $P$. drummondii have been collected.

As is commonly observed in this genus, diminutive plants are capable of flowering, presumably under unfavourable conditions. For instance, Lothian 1629 includes a plant with only three fruiting scapes, scarcely $2.5 \mathrm{~cm}$ tall and bearing a total of only 6 flowers, but setting fruit and seeds of approximately normal size. Well-grown plants form large rosettes, up to $23 \mathrm{~cm}$ diam., with very numerous leaves and scapes.

\section{(2) Features and status of $P$. exilis}

\section{Plantago exilis Decaisne in Candolle, Prodr. 13 (1): 702 (1852).}

LectotyPe (here designated): N. Holl. -Riv. des Cygnes, Preiss 1968, 1843 [the protologue and the label on an isolectotype suggest that the date of collection was actually June 1839 and the isolect totype provides further locality information] (P. 2 sheets!, photos NSW, la belled as 'Plantago debilis R. Br. ex Nees' and 'exilis'). IsolectotyPE: Swan River. In arenosis umbrosis sylvae prope oram maritimam Perth. Preiss 1968, June 1839, ex Herb. E. Drake (P).

Decaisne (1.c.) cites two collections of P. exilis, viz. Preiss 1968 and 1969 The latter is from Rottnest (as Rotnest) Island but was apparently not seen by Pilger in his examination of specimens in $\mathrm{P}$ and $\mathrm{I}$ have not examined it.

This species, of sect. Mesembrynia, was synonymized under $P$. varia $\mathrm{R}$. Br. by Pilger in Engler, Pflanzenr. 269, Heft. 102: 269 (1937); it has not generally been recognized in Australian Floras.

Perennial with a rather stout taproot. Leaves all basal, terect, narrow-elliptic, $8.5-23 \mathrm{~cm}$ long (including petiole which \pm equals lamina), $(0.4-) 1-2 \mathrm{~cm}$ wide, $3(-5)$ nerved, thin-textured, pilose with spreading hairs, entire or usually with a few teeth (the teeth from shallow and very obtuse to prominent, retrorse and acute), the apex acute or obtuse, the base tapering very gradually to the slender petiole, the axil with inconspicuous pale brown hairs. Scapes $9-30 \mathrm{~cm}$ long, 0.6-1.8 $\mathrm{mm}$ diam., with an indumentum of soft short hairs spreading throughout or appressed on the upper half. Spikes (2-) 5-10 cm long, the lower flowers usually widely spaced in. fruiting stage. Bracts narrow-elliptic or narrow-deltoid, $1.8-2.5 \mathrm{~mm}$ long, $0.7-1.5 \mathrm{~mm}$ wide, keeled, the thickened central zone c. $\frac{1}{2}$ the total width, green or purplish, pilose or glabrous abaxially, the margins ciliate. Sepals broad elliptic, $2.6-4 \mathrm{~mm}$ long, $1.4-1.6 \mathrm{~mm}$ wide, keeled, the thickened and usually pilose central zone c. $\frac{1}{4}$ of the total width, green or purplish, the margins ciliate. Corolla: tube $2.6-3.8 \mathrm{~mm}$ long; lobes ovate-deltoid 1.6-2.5 mm long. Stamens: filaments c. $4.5 \mathrm{~mm}$ long, anthers $1.4-1.6$ mm long. Ovules 5. Capsule ovoid-conical, pale, mostly obtuse with a short mucro, $2.8-3.5 \mathrm{~mm}$ long, $1.3-2.0 \mathrm{~mm}$ broad, the upper deciduous portion $2.2-2.6 \mathrm{~mm}$ long. Seeds yellow-brown ellipsoidal, 1-1.5 mm long, 0.8-1.2 mm broad, biconvex or flattened adaxially, the apical ovule commonly developing but often only a single seed in each of the lower loculi. 
Distribution: Recorded only from the Darling and Eyre districts of southern Western Australia.

Specimens Examined: Western Australia: Darling: Swan View (Perth), Andrews, 9.1901 (PERTH); Helena R., Fitzgerald NSW 137344, 9.1900 (NSW); North Fremantle, Helms NSW 137342, 7.1897 (NSW); Kelmscott, Helms NSW 137340, NSW 137341, 9.1898 (NSW); N. Holl,-Riv. des Cygnes [Swan R], Preiss 1970, 1843 (P. photo NSW) cited by Nees in Lehmann, Pl. Preiss, 1: 491 (1845) as 'in solo sublimoso prope Beljarup, Goderich, Octobri a 1840. Herb. Preiss No. 1970'. Eyre: Cranbrook, Diels \& Pritzel 490, 10.1901 (PERTH); Gibson, N. of Esperance, Royce 3750, 8.1950 (PERTH).

$P$. exilis shows general resemblance to $P$. debilis $\mathrm{R}$. Br. in leaf and scape number and dimensions, as well as in leaf texture. However, the rootstock, floral dimensions and some other features suggest closer affinity to P. hispida R. Br. (Table 1).

\section{TABLE 1}

Features of $P$. exilis and of allied Australian species (principal features distinguishing other species from $P$. exilis in italics).

\begin{tabular}{|c|c|c|c|c|}
\hline & exilis & hispida & debilis & varia \\
\hline Taproot .. & stout & stout & usually slender & stout \\
\hline Leaves .. & narrow-elliptic & $\begin{array}{l}\text { narrow-elliptic to } \\
\text { oblanceolate }\end{array}$ & $\begin{array}{l}\text { oblanceolate } \\
\text { or obovate }\end{array}$ & narrow-elliptic \\
\hline Leaf length & $8.5-23 \mathrm{~cm}$ & $(2-) 4-9(-16) \mathrm{cm}$ & $3-15(-25) \mathrm{cm}$ & $6-20 \mathrm{~cm}$ \\
\hline Axillary hairs & pale brown & $\begin{array}{l}\text { white or pale } \\
\text { yellow-brown }\end{array}$ & pale brown & reddish brown \\
\hline $\begin{array}{l}\text { Hairs on lower } \frac{1}{2} \text { of } \\
\text { scape. }\end{array}$ & spreading & $\begin{array}{l}\text { spreading or } \\
\pm \text { appressed }\end{array}$ & appressed & \pm appressed \\
\hline $\begin{array}{l}\text { Hairs on adaxial } \\
\text { surface of leaf. }\end{array}$ & stout but soft & slender & slender & slender \\
\hline Sepal length & $2.6-4 \mathrm{~mm}$ & $2.2-2.8(-3.0) \mathrm{mm}$ & $1.5-2.2(-3.0) \mathrm{mm}$ & $2.8-3.5(-4.0) \mathrm{mm}$ \\
\hline $\begin{array}{l}\text { Length corolla } \\
\text { lobes. }\end{array}$ & $1.6-2.5 \mathrm{~mm}$ & $1.3-1.5 \mathrm{~mm}$ & $0.8-1 \mathrm{~mm}$ & $1.5-2.3 \mathrm{~mm}$ \\
\hline
\end{tabular}

(3) $P$. varia var. exigua: a synonym of $P$. debilis (1937).

Plantago varia $R . B r$. var. exigua Pilger in Engler, Pflanzenr. 269, Heft 102: 269

Holotype: Nouvelle Holl. Swan R., Mr James Drummond $714(\mathrm{G})$. This was compared with Lakeside, SW. of Cue, W. V. Fitzgerald 8.1898 (NSW 102421) by G. Chippendale (letter 16.3.1973) who notes that NSW 102421 'is an exact match for Drummond's specimen in size, appearance and vestiture, and also in the shape and size of the sepals'.

Probable Isotype: Swan River, Drummond 1839 (K), also reported by Chippendale as an excellent match for NSW 102421.

Reference was made to this variety by Briggs, Carolin \& Pulley (1977), noting that it appeared specifically distinct from $P$. varia $\mathrm{R}$. Br. 'but the name $P$. exigua is preoccupied and a new name will be published elsewhere'. I have now examined further specimens and consider that $P$. varia var. exigua is probably a synonym of $P$. debilis $\mathrm{R}$. Br., not deserving recognition at either specific or subspecific rank. 
In Western Australia, as elsewhere, the name $P$. varia has been misapplied to several species, including $P$. debilis. The former is a species of eastern Australia, occurring mainly in the cooler tableland and southern regions. $P$. debilis appears not to have been recorded in Western Australia in recent publications. Collections are few but widely scattered in the phytogeographic regions (Beard, 1979) of Austin (Gibraltar, Lakeside), Irwin (Houtmans Abrolhos and Mingenew), Drummond (Garden Is.), and Eyre (Jacup SW. of Ravensthorpe). The last locality is the only one accompanied by a habitat note, 'among grass in shady valley', consistent with habitats of $P$. debilis in eastern Australia.

Western Australian specimens are smaller, narrower-leaved, and with inflorescences more compact and more pilose than is usual in $P$. debilis elsewhere, but no fully consistent differences have been noted. These specimens closely resemble depauperate plants of $P$. hispida $\mathrm{R}$. Br. but differ in their apparently annual habit, slender taproot, narrower petals, smaller anthers and more membranous capsule. Both species include occasional subglabrous plants, particularly in sea-coast sites. $P$. hispida is known from southern Western Australia, east of Albany (Pallinup River, Lort River, and Cape Le Grand).

\section{ACKNOWLEDGEMENTS}

I wish to thank Mr George Chippendale of the Division of Forest Research, CSIRO, Canberra, for examining and reporting upon type material at $\mathrm{K}$ and $\mathrm{G}$. I am also indebted to the late Mr John Carrick of the State Herbarium of South Australia for assistance in the typification of $P$. exilis. The loan of specimens from or opportunity to examine material at $\mathrm{P}, \mathrm{K}, \mathrm{AD}, \mathrm{ADW}$, and PERTH is gratefully acknowledged.

\section{REFERENCES}

Beard, J. S. (1979). Phytogeographic regions. In Gentilli, J. (Ed.), 'Western Landscapes.' pp. 107-121. (Univ. Western Australia Press: Perth.)

Briggs, B. G., Carolin, R. C. and Pulley, J. M. (1977). Plantaginaceae. Flora of New South Wales, family No. 181: 1-35.

Eardley, C. M. (1946). The Simpson Desert Expedition, 1939-Scientific Reports No. 7, Botany-Part I: Catalogue of Plants. Trans. Roy. Soc. South Australia 70: $145-174$.

Symon, D. E. (1969). A checklist of flowering plants of the Simpson Desert and its immediate environs. Trans. Roy. Soc. South Australia 93: 17-38. 